\title{
Pengaruh Terapi Massage Counterpressure Terhadap Nyeri Kala I Pada Ibu Inpartu Di BPS Desa Durjan, Bangkalan
}

\author{
Astrida Budiarti ${ }^{1}$, Aimmatus Solicha ${ }^{2}$ \\ ${ }^{1,2}$ Stikes Hang Tuah Surabaya \\ email : as3dans@yahoo.com
}

\begin{abstract}
Abstrak
Proses persalinan dimulai pada saat terjadi kontraksi uterus yang teratur dan progresif serta akan diakhiri dengan keluarnya janin. Massage counterpressure merupakan salah satu terapi non farmakologi, massage counterpressure dapat menimbulkan efek relaksasi dan menurunkan nyeri. Penelitian ini bertujuan untuk menganalisa pengaruh terapi massage counterpressure terhadap nyeri kala I pada ibu inpartu.Desain penelitian ini adalah quasy eksperiment dengan pendekatan the static group comparism. Sampel dalam penelitian ini adalah 23 responden yang dipilih secara accidental sampling. Instrumen penelitian menggunakan lembar kuisioner dan lembar observasi. Data analisa dengan uji Mann Whitney U-Test.Hasil penelitian menunjukkan bahwa massage counterpressure berpengaruh terhadap penurunan nyeri kala I pada ibu inpartu. Melalui uji statistik Man Whitney UTest menunjukkan ada pengaruh yang signifikan $\rho=0,000(\alpha<0,05)$. Disimpulkan terapi masssage counterpressure berpengaruh terhadap nyeri kala I pada ibu inpartu.Implikasi penelitian ini adalah massage counterpressure berpengaruh terhadap nyeri kala I, sehingga BPS Desa Durjan, Bangkalan dapat memanfaatkan massage counterpressure dalam ngontrol nyeri kala I.
\end{abstract}

Kata kunci: Nyeri kala I, Counterpressure

\section{Pendahuluan}

Nyeri persalinan timbul karena kontraksi miometrium, dan hal ini merupakan proses fisiologis dengan intensitas yang berbeda pada masing-masing individu. Nyeri persalinan, yang timbul mengakibatkan kekhawatiran dan biasanya menimbulkan rasa takut dan stress yang dapat mengakibatkan pengurangan aliran darah ibu-janin (Andarmoyo \& Suhartini. 2013).

Nyeri persalinan merupakan proses fisiologis sehingga adanya nyeri tersebut dicari, nyeri yang timbul dapat mengakibatkan kekhawatiran dan biasanya menimbulkan rasa takut dan stress sehingga perlu intervensi untuk mengurangi nyeri persalinan agar ibu bisa beradaptasi dengan nyeri tersebut. Terdapat banyak metode untuk mengurangi nyeri persalinan salah satunya dengan metode nonfarmakologis, yaitu distraksi, relaksasi, hypnobrithing, salah satunya bisa dilaksanaka dengan metode masssagecounterpressure. Penggunaan metode massage counterpressure di BPS
Desa Durjan, Bangkalan selama ini belum umum dilakukan serta belum diketahui keefektifannya bagi ibu melahirkan di BPS Desa Durjan, Bangkalan.

World Health Organization (WHO) memperkirakan setiap tahun terjadi 210 juta kehamilan diseluruh dunia, dari jumlah ini 20 juta perempuan mengalami kesakitan akibat persalinan (Prawirohardjo, 2008 dalam Wahyuningsih, 2014). Rahmawati dan Dharmaningrum (2011) mengatakan nyeri persalinan khususnya kala I lebih banyak dirasakan pada primipara yaitu sebesar $59,38 \%$ sedangkan pada multipara sebesar 40,62\% (Dwitanti, F. 2014). Berdasarkan data survei pendahuluan yang dilakukan pada bulan Februari 2015 di BPS Desa Durjan, Bangkalan peneliti melakukan observasi kepada 4 ibu didapatkan hasil bahwa 4 ibu yang mengalami persalinan merasakan nyeri skala 4 pada kala I.

Penyebab nyeri persalinan pada kala I berasal dari dilatasi serviks, dimana sumber nyeri yang utama, peregangan segmen uterus 
bawah, tekanan pada struktur-struktur yang berdekatan, hipoksia pada sel-sel uterus selama kontraksi. Area nyeri meliputi dinding abdomen bawah dan area-area pada bagian lumbal bawah dan sakrum atas.

Nyeri pada persalinan dapat mempengaruhi psikologi, penderitaan, ketakutan, dan kecemasan, kardiovaskuler, peningkatan cardiac output, tekanan darah, frekuensi nadi dan resistensi perifer sistemik, metabolik, peningkatan kebutuhan $\mathrm{O} 2$, asidosis laktat, hipergllikemi, liposis, rahim/uterus, inkordinasi kontraksi uterus/rahim, fetus, asidosi akibat hipoksia pada janin (Maryunani, 2012).

Banyak cara yang dapat dilakukan untuk mengurangi nyeri pada saat persalinan, cara tersebut antara lain tindakan farmakologis dan non farmakologis. Tindakan farmakologis hampir semua mempunyai efek samping pada ibu dan janin (Andarmoyo \& Suharti, 2013). Tindakan manajemen nyeri non farmakologis membantu mengurangi nyeri dengan mengubah persepsi nyeri dan aman. Massage merupakan teknik kuno yang telah banyak digunakan selama persalinan. Massage bekerja dengan baik dalam memblokir impuls nyeri ke otak dan merangsang pelepasan endorfin lokal (hormon yang berguna untuk menurunkan nyeri). Dasar teori masase adalah teori gate control yang dikemukakan oleh Melzak dan Wall (1965, dalam Murray \& Huelsmann, 2013). Massage atau pijatan, efektif dalam memberikan relaksasi fisik dan mental, mengurangi nyeri, dan meningkatkan keefektifan pengobatan nyeri. Massage pada punggung, bahu, lengan, dan / atau kaki selama 3 sampai 5 menit dapat merelaksasi otot dan memberikan istirahat yang tenang dan kenyamanan (Perry \& Potter, 2010). Perawat yang mendampingi proses persalinan diharapkan menerapkan metode pengurang nyeri secara nonfarmakologis salah satunya dengan metode massage counterpressure.

\section{Bahan dan Metode Penelitian}

Penelitian ini menggunakan rancangan penelitian quasy eksperiment dengan pendekatan the static group comparism dengan cara melibatkan dua kelompok subjek yaitu kelompok perlakuan dan kelompok kontrol.

Penelitian ini dilakukan pada tanggal 20 Mei 2015 - 30 Juni 2015 di BPS Ny. HP dan Ny. H Desa Durjan. Bangkalan. Populasi dalam penelitian ini adalah $23 \mathrm{ibu}$ inpartu di BPS Desa Durjan, Bangkalan. Teknik pengambilan sampel pada penelitian ini adalah sampling aksidental. Sample dalam penelitian ini adalah $23 \mathrm{ibu}$ inpartu kala I yang memenuhi kriteria inklusi dan eksklusi yaitu 12 ibu inpartu primipara di BPS Ny. H dan 11 ibu inpartu primipara di BPS Ny. HP Desa Durjan, Bangkalan.

Bentuk instrumen pengumpulan data yang digunakan adalah lembar kuisioner dan lembar observasi pengukuran nyeri (menggunakan Face pain rating scales).

\section{Data Umum}

1. Karakteristik Responden Berdasarkan Usia.

Penelitian menunjukkan dari 11 responden dengan karakteristik berdasarkan usia pada kelompok kontrol sebagian besar usia ibu inpartu berusia 20-35 sebanyak 10 responden $(83,3 \%)$, usia $<20$ sebanyak 2 responden $(16,7 \%)$. Sedangkan 12 responden dengan karakteristik berdasarkan usia pada kelompok perlakuan sebagian besar usia ibu inpartu berusia 20-35 sebanyak 10 responden ( 90,9\%), usia $<20$ sebanyak 1 responden $(9,1 \%)$.

2. Karakteristik Responden Berdasarkan Pendidikan.

Penelitian menunjukkan bahwa dari 12 reponden dengan karakteristik berdasarkan pendidikan pada kelompok kontrol sebagian besar ibu inpartu berpendidikan SMP/sederajat sebanyak 7 responden $(58,3 \%)$, berpendidikan SMA/sederajat sebanyak 3 responden 
(25,0 \%), berpendidikan $\mathrm{SD} /$ sederajat sebanyak 2 responden (16,7 \%). Sedangkan 11 responden dengan karakteristik berdasarkan pendidikan pada kelompok perlakuan adalah ibu inpartu berpendidikan $\mathrm{SMP} /$ sederajat sebanyak 5 responden $(45,5 \%)$, berpendidikan SMA/sederajat sebanyak 4 responden $(36,4 \%)$, berpendidikan $\mathrm{SD} /$ sederajat sebanyak 1 responden $(9,1$ $\%$ ), tidak sekolah atau tidak tamat SD sebanyak 1 responden $(9,1 \%)$.

3. Karakteristik Responden Berdasarkan Status Pendamping Saat Melahirkan.

Penelitian menunjukkan bahwa dari 12 responden dengan karakteristik berdasarkan status pendamping saat melahirkan pada kelompok kontrol semua ibu inpartu didampingi adalah sebanyak 12 responden (100\%). Sebanyak 11 responden dengan karakteristik berdasarkan status pendamping saat melahirkan pada kelompok perlakuan semua ibu inpartu didampingi oleh keluarga adalah sebanyak 11 responden $(100 \%)$.

\section{Data Khusus}

1. Tingkat Nyeri Ibu Inpartu Kala I Pada Kelompok Tidak Diberikan Terapi Massage Counterpressure di BPS Desa Durjan Bangkalan

Penelitian menunjukkan dari 12 responden pada kelompok yang tidak diberikan terapi massage counterpressure adalah 8 responden $(66,7 \%)$ mengalami nyeri skala 4,3 responden $(25,0 \%)$ mengalami nyeri skala 3,1 responden $(8,3 \%)$.

2. Tingkat Nyeri Ibu Inpartu Kala I Pada Kelompok Dengan Pemberian Terapi Massage Conuterpressure di BPS Desa Durjan Bangkalan.

Penelitian menunjukkan dari dari 11 responden pada kelompok dengan pemberian terapi massage counterpressure adalah sebanyak 6 responden $(54,5 \%)$ mengalami nyeri skala 1, 4 responden $(36,4 \%)$ mengalami nyeri skala 2,1 responden $(9,1 \%)$ mengalami nyeri skala 5 .

3. Pengaruh Terapi Massage Counter Pressure Terhadap Nyeri Kala I Pada Ibu Inpartu di BPS Desa Durjan Bangkalan

\begin{tabular}{ccccc}
\hline $\begin{array}{c}\text { Tingkat } \\
\text { Nyeri }\end{array}$ & $\begin{array}{c}\text { Kelompok } \\
\text { Kontrol }\end{array}$ & $\begin{array}{c}\text { (\%) } \\
\text { Perlakuan }\end{array}$ & $\begin{array}{c}\text { Kelompok } \\
(\%)\end{array}$ \\
\hline Skala 0 & 0 & 0,0 & 0 & 0,0 \\
Skala 1 & 0 & 0,0 & 6 & 54,5 \\
Skala 2 & 0 & 0,0 & 4 & 36,4 \\
Skala 3 & 3 & 25,0 & 1 & 9,1 \\
Skala 4 & 8 & 66,7 & 0 & 0,0 \\
Skala 5 & 1 & 8,3 & 0 & 0,0 \\
Jumlah & 12 & 100,0 & 11 & 100,0 \\
\hline Hasil uji statistik Mann-Whitney U Test $\rho=0,000(\alpha<$ \\
\multicolumn{5}{c}{$0,05)$} \\
\hline
\end{tabular}

Sebanyak 12 responden pada kelompok kontrol sebagian besar responden mengalami nyeri skala 4 yaitu sebanyak 8 responden $(66,7 \%), 3$ responden $(25,0 \%)$ mengalami nyeri skala 3,1 responden $(8,3 \%)$ mengalami nyeri skala 1 , sedangkan dari 11 responden pada kelompok perlakuan 6 responden $(54,5 \%)$ mengalami nyeri skala 1 , 4 responden $(36,4 \%)$ mengalami nyeri skala 2,1 responden $(9,1 \%)$ mengalami nyeri skala 3. Hasil uji statistik menggunakan uji MannWhitney didapatkan nilai $\rho=0,000$ yang berarti $\rho<0,05$ sehingga dapat disimpulkan bahwa ada pengaruh yang signifikan terapi massage counterpressure terhadap nyeri kala 1 pada ibu inpartu.

\section{Pembahasan}

1. Tingkat Nyeri Kala I Pada Ibu Inpartu Pada Kelompok Yang Tidak Diberikan Terapi Massage Counterpressure.

Penelitian menunjukkan bahwa sebagian besar ibu inpartu pada kelompok kontrol mengalami nyeri skala 4 sebanyak 8 responden $(66,7 \%), 3$ responden $(25,0 \%)$ mengalami nyeri skala 3,1 responden $(8,3 \%)$ mengalami nyeri skala 1. Rasa nyeri merupakan suatu hal yang bersifat kompleks, mencakup beberapa faktor yaitu usia, 
kondisi psikologis, pengalaman nyeri sebelumnya (Perry \& Potter, 2010). Menurut Mayurnani (2010) respon terhadap nyeri juga bisa dipengaruhi oleh persiapan persalinan, support system, serta pengertian terhadap nyeri itu sendiri. Salah satu faktor yang mempengaruhi nyeri adalah faktor usia. Penelitian menunjukkan bahwa dari 12 responden sebagian besar responden berusia 20-35 tahum yaitu 10 responden berusia $20-35$ tahun $(83,3 \%), 2$ responden $(16,7 \%)$ berusia $<20$ tahun. Hasil data crosstab menjelaskan bahwa dari 10 responden berusia $20-35$ tahun $(70,0 \%)$ responden mengalami nyeri skala 4 , dari 2 responden berusia $<20$ tahun $(50,0 \%)$ mengalami nyeri skala 5 . Hal ini sesuai dengan teori (Andarmoyo, 2013) menyebutkan usia muda cenderung dikaitkan dengan kondisi psikologis yang masih labil, yang memicu terjadinya kecemasan dan rasa takut yang berlebih sehingga nyeri yang dirasakan menjadi semakin berat. Semakin meningkat usia seseorang maka semakin banyak pengalaman yang akan meningkatkan pemahaman terhadap nyeri.

Faktor lain yang mempengaruhi nyeri adalah kondisi psikologis ibu inpartu. Penelitian menunjukkan bahwa dari 12 responden sebagian besar responden mengalami stress yaitu 10 responden $(83,3 \%)$ mengalami stress, 2 responden $(16,7 \%)$ tidak mengalami stress. Hal ini di buktikan dari hasil data crosstab bahwa dari 10 responden yang mengalami stress $(80,0 \%)$ mengalami nyeri skala 4. Menurut Andarmoyo \& Suharti (2013) situasi dan kondisi psikologis yang labil memegang peranan penting dalam memunculkan nyeri persalinan yang lebih berat. Kecemasan terkadang meningkatkan persepsi terhadap nyeri, tetapi nyeri juga menyebabkan perasaan cemas (Perry \& Potter, 2010). Tingkat nyeri yang berbeda-beda pada responden juga dikarenakan rasa cemas, takut, serta mekanisme koping terhadap nyeri itu sendiri.

Faktor lain yang dapat mempengaruhi nyeri adalah persiapan persalinan. Hasil penelitian menunjukkan bahwa dari 12 responden 100,0\% responden tidak mendapat informasi teknik penurunan nyeri. Hasil data crosstab menjelaskan bahwa dari 12 responden yang tidak mendapat informasi teknik penurunan nyeri $(66,7 \%)$ responden mengalami nyeri skala 4 . Menurut Mayurnani (2010) pada kelas persiapan calon ayah dan ibu akan mendapatkan informasi yang tepat tentang persalinan, mengurangi rasa takut, meningkatkan kemampuan untuk menghadapi sakit dan menambah kemampuan untuk mengambil keputusan. Pada kelas persiapan persalinan juga diajarkan tentang teknik- teknik relaksasi, pengalihan rasa sakit atau distraksi, kontrol otot, dan pernapasan serta senam hamil yang bertujuan agar proses persalinan yang akan dihadapi nanti berjalan lancar. persiapan persalinan merupakan hal yang harus diikuti karena dalam proses mengikuti persiapan persalinan calon ayah dan ibu akan lebih siap secara fisik maupun psikis.

\section{Tingkat Nyeri Kala I Pada Ibu Inpartu Pada Kelompok Yang Diberikan Terapi Massage Counter Pressure}

Penelitian menunjukkan 11 responden yang mendapat terapi massage counter pressure sebanyak $6(54,5 \%)$ responden mengalami nyeri skala 1,4 responden $(36,4 \%)$ mengalami nyeri skala 3,1 responden $(9,1 \%)$ mengalami nyeri skala 5. Pemberian massagecounterpressure dapat menutup gerbang pesan nyeri yang akan dihantarkan menuju medulla spinalis dan otak, selain itu tekanan kuat pada teknik massage counter pressure dapat mengaktifkan senyawa endhorpine yang 
berada di sinaps sel- sel saraf tulang belakang dan otak, sehingga transmisi dari pesan nyeri dapat dihambat sehingga menyebabkan status penurunan sensai nyeri (Rejeki, et al, 2012). Berdasarkan asumsi peneliti, massage counterpressure merupakan terapi yang dapat digunakan sebagai pengelola rasa nyeri, mengurangi tingkat ketegangan otot. Selain itu massage merangsang tubuh melepaskan senyawa endhorphin yang dapat menurunkan nyeri secara alamiah sehingga merasa lebih rileks dan nyaman.

Menurut Zwelling (2006, dalam Elsevier 2013) nyeri saat persalinan berbeda pada tiap wanita. Salah satu faktor yang mempengaruhi nyeri persalinan adalah usia. Hasil penelitian menunjukkan bahwa dari 11 responden 10 responden berusia 20-35 tahun, 1 responden berusia $<20$ tahun. Hasil data crosstab menjelaskan bahwa 10 dari reponden berusia $20-35$ tahun $(60 \%)$ responden mengalami nyeri skala 1 . Menurut Perry \& Potter (2010). Usia dapat mempengaruhi nyeri, terutama pada bayi dan dewasa akhir. Semakin meningkat usia seseorang maka semakin banyak pengalaman yang akan meningkatkan pemahaman terhadap nyeri

Faktor lain yang mempengaruhi adalah kondisi psikologis ibu inpartu. Berdasrkan hasil penelitian dari 11 responden 7 responden $(63,6 \%)$ mengalami stress, 4 responden $(36,4 \%)$ tidak mengalami stress. Hasil data crosstab menunjukkan bahwa dari 4 responden yang tidak mengalami stress $(100,0 \%)$ mengalami nyeri skala 1 . Menurut Damayanti (2015) nyeri dan rasa sakit yang berlebihan akan menimbulkan rasa cemas. Takut, cemas dan tegang memicu produksi hormon prostaglandin sehingga menimbulkan stress.. Rasa takut dan cemas yang berlebihan menimbulkan stress akan memperparah tingkat nyeri sehingga bila sesorang merasa lebih tenang tingkat nyeri yang dirasakan lebih rendah.

Faktor lain yang mempengaruhi nyeri adalah support system atau dukungan dari keluarga saat melahirkan. Penelitian menunjukkan bahwa dari 11 responden semua responden $(100,0 \%)$ didampingi saat melahirkan. Hasil data crosstab menunjukkan bahwa dari 11 responden yang didampingi saat melahirkan $\quad(54,5 \%) \quad$ responden mengalami nyeri skala 1 . Tersedianya sarana dan supportsystem yang baik dari lingkungan dalam mengatasi nyeri, dukungan dari keluarga dan orang terdekat sangat membantu mengurangi rangsang nyeri yang dialami oleh seseorang saat menghadapi persalinan (Andarmoyo, 2013). Dukungan dari keluarga atau orang terdekat dapat memberikan rasa nyaman, aman saat seorang ibu menghadapi persalinan sehingga dapat membantu mengurangi rasa cemas dan reaksi fisik terhadap nyeri.

\section{Pengaruh Terapi Massage Counter Pressure Terhadap Tingkat Nyeri Kala I Pada Ibu Inpartu}

Hasil uji statistik menggunakan uji Mann-Whitney didapatkan nilai $\rho=$ 0,000 yang berarti $\rho<0,05$ dengan demikian dapat disimpulkan bahwa massage counter pressure berpengaruh terhadap penurunan tingkat nyeri kala I pada ibu inpartu. Hasil penelititan ini menunjukkan bahwa tingkat nyeri kala I pada kelompok yang mendapat terapi massage counterpressure lebih rendah dibandingkan pada kelompok kontrol. Hal ini terjadi karena massage counterpressure memblokir impuls nyeri yang akan menuju ke otak sehingga sensari nyeri yang dirasakan ibu inpartu berkurang (Mayurnani, 2010). Selain itu dengan pemberian massage dapat membantu ibu merasa lebih relaks, dan nyaman selama persalinan. Hal itu karena 
massage merangsang tubuh melepaskan senyawa endorphin dan juga menciptakan perasaan nyaman dan enak (Danuatmaja \& Meiliasari, 2008).

Menurut Andarmoyo (2013) massage adalah melakukan tekanan tangan pada jaringan lunak, biasanya otot, tendon, atau ligamentum, tanpa menyebabkan gerakan atau perubahan posisi sendi untuk meredakan nyeri, menghasilkan relaksasi, dan/atau memperbaiki sirkulasi. Counterpressure merupakan teknik massage dengan memberikan tekanan yang menetap yang diberikan seseorang dengan menekan kepalan atau bagian bawah telapak tangan ke daerah sakral. Teknik ini membantu mengatasi sensasi tekanan dari dalam dan rasa nyeri di punggung bawah (Elsevier, 2013). Sebuah penelitian menyebutkan ibu yang di massage 20 menit setiap jam selama tahap persalinan akan lebih bebas dari rasa sakit. Hal ini dikarenakan massage merangsang tubuh melepaskan senyawa endhorpine yang dapat menghilangkan sakit secara alamiah sehingga lebih nyaman (Danuatmaja, 2008).

Dalam penelitian ini didapatkan hasil bahwa terjadi penurunan tingkat nyeri pada kelompok yang mendapat terapi massage counter pressure. Salah satu hal yang dapat menurunkan tingkat nyeri adalah karena pemberian massage counter pressure bekerja dengan cara saraf A-beta mendominasi transmisi serabut A-delta dan $\mathrm{C}$ yang berdiameter kecil, sehingga menurunkan transmisi nyeri yang dihantarkan melalui serabut A-delta dan $\mathrm{C}$ dengan cara memblok sinaps ke substansi gelatinosa untuk menghambat transmisi impuls nyeri (Prasetyo, 2010). Massage membantu ibu merasa lebih rileks, dan nyaman selama persalinan

Hasil penelitian ini sesuai dengan teory gate control menurut Melzack \& Wall (1965) teori tersebut mengatakan bahwa keberadaan dan intensitas pengalaman nyeri tergantung pada transmisi tertentu pada impuls-impuls saraf. Mekanisme gate/pintu sepanjang sistem saraf mengontrol/mengendalikan transmisi nyeri. Nyeri akan melewati gerbang ketika gate/gerbang dalam posisi terbuka, impuls yang menyebabkan sensasi nyeri dapat mencapai tingkat kesadaran. Jika gate tertutup, impuls tidak mencapai tingkat kesadaran dan sensasi nyeri tidak dialami.Aktifitas dalam serat-serat saraf besar dan kecil yang mempengaruhi sensasi nyeri. Impuls nyeri melalui serat-serat yang berdiameter kecil. Serat-serat saraf yang berdiameter menututp gate pada impuls yang melalui serat-serat kecil. Teknik yang menggunakan stimulasi kutaneous pada kulit, yang mempunyai banyak serat berdiameter besar, bisa membantu menutup gate pada transmisi impuls yang menimbulkan nyeri, dengan cara demikian meringankan sensasi nyeri (Mayurnani, 2010). Selain itu tindakan massage counterpressure dapat juga dijelaskan menggunakan dasar teori opiate endogenous. Tindakan massage itu sendiri dapat menyebabkan peningkatan endorphin. Endorphin mempengaruhi transmisi impuls yang diinterpretasikan sebagai nyeri. Endorphine bertindak sebagai neurotransmitter maupun neuromodulator yang menghambat transmisi dari pesan nyeri. Adanya endorphin pada sinaps sel-sel saraf menyebakan status penurunan dalam sensasi nyeri.

Berdasarkan uraian diatas peneliti
berpendapat bahwa nyeri bisa
dipengaruhi oleh persepsi nyeri yang
dirasakan dan reaksi nyeri yang
merupakan respon seseorang terhadap
nyeri dapat dipengaruhi oleh usia, kondisi
psikologis, dan pengalaman nyeri
sebelumnya. Nyeri ini dapat diatasi
dengan menggunakan terapi massage
counterpressure.
Massage


counterpressure bekerja dengan cara saraf A-beta mendominasi transmisi serabut A-delta dan $\mathrm{C}$ yang berdiameter kecil, sehingga menurunkan transmisi nyeri, selain itu massagecounterpressure memberikan rasa lebih tenang, nyaman dan rileks serta lebih dekat dengan petugas kesehatan yang melayani secara tidak langsung hal ini dapat mengurangi nyeri yang dirasakan.

\section{Kesimpulan}

Berdasarkan hasil penelitian yang telah dilakukan oleh peneliti di BPS Desa Durjan, Bangkalan pada bulan mei 2015 dapat ditarik kesimpulan sebagai berikut:

1. Tingkat nyeri kala I pada ibu inpartu yang tidak diberikan massage counter pressure adalah nyeri skala 4

2. Tingkat nyeri kala I pada ibu inpartu yang diberikan terapi massage counter pressure adalah nyeri skala 1

3. Ada pengaruh terapi massage counter pressure terhadap nyeri kala I pada ibu inpartu dengan nilai $\rho=0,000$

\section{Saran}

1. Bagi Petugas kesehatan

Diharapkan dapat mengaplikasikan tindakan ini untuk menangani masalah nyeri persalinan kala I.

2. Bagi Masyarakat

Dari penelitian ini diharapkan masyarakat khususnya ibu inpartu nyeri kala I mampu mengenal terapi massage counter-pressure serta fungsinya terhadap nyeri kala I.

\section{Daftar Pustaka}

Andarmoyo, S., Suharti. (2013). Persalinan Tanpa Nyeri Berlebihan. Jakarta: AM.

Bobak, Lowdermik, et al. (2012). Buku Ajar Keperawatan Maternitas, edisi 4. Jakarta: EGC

Danuatmaja, B., Meiliasari, M. (2008). Persalinan Normal Tanpa Rasa Sakit. Jakarta: Puspa Suara.
Dwitanti, F. A. (2014). Pengaruh Terapi Musik Mozaed Terhadap Prnurunan Nyeri Persalinan Kala I Fase Laten Pada Primipara.

Ferry, Wong. (2011). Panduan Lengkap Pijat. Jakarta: Penebar Plus

Mayurnani, A. (2012). Nyeri dalam Persalinan: Teknik dan Cara Penanganannya: Jakarta. TIM

Murray., Huelsmann. (2013). Persalinan \& Melahirkan Praktik Berbasis Bukti. Jakarta: EGC

Novita, Regina. V. T. (2011). Keperawatan Maternitas. Jakarta: Ghalia Indonesia

Potter, P.A \& Perry, A. G. (2010). Buku Ajar Fundamental Keperawatan: Konsep, Proses, dan Praktik Edisi 7 buku 3, Jakarta: Salemba Medika.

Prasetyo, Sigit P. 2010. Konsep dan Proses Keperawatan Nyeri. Yogyakarta: Graha Ilmu

Solehati, T., Kosasih, C. E. (2015). Konsep dan Aplikasi Relaksasi Dalam Keperawatan. Bandung: Refika Aditama. 